\title{
Monsoon Driven Plankton Variation in Trincomalee Coastal Waters
}

\author{
Priyadarshani W.N.C. ${ }^{1 *}$, Prasad J.A.C. ${ }^{1}$, Ranatunga R.R.M.K.P. ${ }^{2}$ and Jayasiri H.B. ${ }^{1}$ \\ ${ }^{I}$ National Aquatic Resources Research and Development Agency, Sri Lanka \\ ${ }^{2}$ Department of Zoology, University of Sri Jayewardenepura, Sri Lanka \\ *nilanthi_priyadarshani@yahoo.com
}

\begin{abstract}
Ecosystem dynamics and nutrient inputs to the coastal water bodies are directly coupled with seasonal fresh water plume formation at marine environment and affect wide range of biogeochemical and physical processes of coastal waters. Trincomalee Bay and adjacent coastal waters are such a distinctive ecosystem which is frequently subjected to alter its biogeochemical processes and cycles by Mahaweli River water discharges with plenty of agrochemicals and organic particulate matters. Present study was conducted in June 2010 to December 2011 in order to monitor both phytoplankton and zooplankton variations with relation to monsoonal driven physico-chemical parameters covering full monsoon cycle, (North-East, South-West, First and Second inter monsoons). Sixteen (16) sampling sites representing three distinctive regions (bay, mouth, and offshore) of Trincomalee coastal waters were subjected for sub surface, (1m depth) sampling (temperature, salinity, nutrients, dissolved oxygen, total suspended solids and plankton), with total area of $450 \mathrm{~km}^{2}$.
\end{abstract}

According to the results, mean phytoplankton abundance varied between 2989-148670 individuals $\mathrm{l}^{-1}$ during four monsoons while maximum and minimum numbers were recorded during North East monsoon at Mahaweli River mouth and second inter monsoon at offshore. The highest abundance $\left(7.73 \times 10^{5}\right.$ individuals $\left.1^{-1}\right)$ was observed in bay area while the lowest abundance (492 individuals $1^{-1}$ ) was recorded in offeshore during North East monsoon. Phytoplankton population was dominated by diatoms (100\%) in bay area during North East monsoon while offshore waters invaded by dinoflagellates (40\%) during same season. Phytoplankton abundance was positively correlated with nutrients [Nitrate-N ( $\mathrm{r}=0.51)$ Nitrite$\mathrm{N}(\mathrm{r}=0.34)$ and phosphate-P $(\mathrm{r}=0.40)$ and Silicate-Si $(\mathrm{r}=0.54)]$ and negatively correlated with salinity $(\mathrm{r}=-0.86)$. There was no significant varaition between phytoplankton abundance and other oceanographic parameters such as temperature, dissolved oxygen and total suspended solids $(\mathrm{P}>0.05)$. Maximum zooplankton (34683 individuals $\mathrm{m}^{-3}$ ) was observed near Mahaweli River discharge points during North East monsoon while minimum (327 individuals $\mathrm{m}^{-3}$ ) recorded at offshore canyon area during $2^{\text {nd }}$ inter monsoon. Here, Calanoids dominated the zooplankton population while abundance was positively correlated with silicate $(\mathrm{r}=0.43)$, phosphate $(\mathrm{r}=0.47)$ and phytoplankton abundance $(\mathrm{r}=0.59)$. Salinity impacted negatively $(\mathrm{r}=-$ 0.52) on zooplankton population while the highest number of groups were found in Koddiyar Bay which is subjected to change in water quality with Mahaweli River discharge. Thus, phytoplankton and zooplankton were maximum at bay during North East monsoon and closely correlated with maximum nutrient concentration carried by Mahaweli run off enriched with eroded soil particles during North East monsoon.

Keywords: Phytoplankton, Zooplankton, Nutrients, River discharge

Proceedings of the International Forestry and Environment Symposium 2016, Department of Forestry and Environmental Science, University of Sri Jayewardenepura, Sri Lanka. 